\title{
EFFECT OF PASTEURIZATION CLAIM ON ACCEPTANCE AND PURCHASE INTENTION OF READY-TO-EAT AÇAÍ
}

\author{
JÉSSICA B. PORTELA* \\ LÍVIA MELLO** \\ TÁBATA F. DA SILVA*** \\ KAREN S. PEREIRA**** \\ LAURO MELO*****
}

\begin{abstract}
The açai (Euterpe oleracea) is very perishable, due to its microbial, chemical and enzymatic nature. Furthermore, extensive handling of the product during the production process also contributes to its rapid deterioration and contamination. Results showed the açai as a vehicle for oral transmission of Acute Chagas disease (ACD). The pasteurization, which is an important thermal process in the food industry, can inactivate the protozoan that transmits the ACD, assuring microbiological food safety. However, heat can affect important sensory characteristics such as color and flavor and decrease açaí acceptance. On the other hand, information about the product can interfere in the consumer's choice and intention to purchase. The study was conducted with two brands of ready-toeat açaí, pasteurized and unpasteurized. Affective acceptance tests were performed with the samples, using the hedonic 9-point scale (1 $=$ dislike extremely to $9=$ like extremely). Moreover, evaluations also included consumption frequency, and purchase intention. Results demonstrated that the pasteurization claim, given to consumers, increased $(p<0.05)$ acceptance of the pasteurized sample $\left(7.5^{\mathrm{a}}\right)$, initially (without the claim) $\left(6.2^{b}\right)$ not as well accepted as the unpasteurized sample $\left(7.8^{a}\right)(p<0.05)$. Despite that, the claim of not pasteurization did not influence the acceptance of the unpasteurized sample $\left(7.8^{a}\right)$, which remained well accepted $(p>0.05)$ by consumers $\left(7.8^{\mathrm{a}}\right)$. These results reinforce the importance of the effect of information on the consumer's acceptance and purchase intention of açaí.
\end{abstract}

KEYWORDS: INFORMATION EFFECT, SENSORY EVALUATION, PROCESS CLAIM.

${ }^{*}$ Food Engineer, Department of Biochemical Engineering, School of Chemistry, Federal University of Rio de Janeiro, Rio de Janeiro, Brazil. jessicabarbosa_jbp@yahoo.com.br

${ }^{* *}$ Food Engineer, Department of Biochemical Engineering, School of Chemistry, Federal University of Rio de Janeiro, Rio de Janeiro, Brazil. livotinha_mello@hotmail.com

${ }^{* * *}$ Food Engineer, Department of Biochemical Engineering, School of Chemistry, Federal University of Rio de Janeiro, Rio de Janeiro, Brazil. tabatapredi@yahoo.com.br

${ }^{* * * * B}$ Biologist, Dr., Department of Biochemical Engineering, School of Chemistry, Federal University of Rio de Janeiro, Rio de Janeiro, Brazil. signori@eq.ufrj.br

${ }^{* * * * *}$ Food Engineer, Dr., Department of Biochemical Engineering, School of Chemistry, Federal University of Rio de Janeiro, Rio de Janeiro, Brazil. lauro@eq.ufrj.br +55 2139387579 (corresponding author) 


\section{INTRODUCTION}

The consumption of açaí has increased and has been driven by its nutritional and functional properties. The açaí is highly perishable due to harvesting practices and post-harvest which it is submitted to in addition to transportation and unfavorable environmental conditions such as high temperatures and high humidity (Menezes, 2005).

The açaí is highly perishable, being very susceptible to microbial action. Also, its enzymatic and chemical nature, results in lipid oxidation reactions, reduction of the levels of anthocyanins and depigmentation of the pulp, changing important sensory and nutritional characteristics of the product (Menezes et al., 2008).

Studies showed that microorganisms associated with food poisoning are related to the contamination of açaí (Sousa et al., 1999) and may be indicative of inadequate practices during the manufacturing process. Moreover, in northern Brazil the product has been appointed as a form of oral transmission of Acute Chagas Disease (ACD) (Brazil, 2012).

Research shows that Trypanosoma cruzi can be delivered orally through the pulp even when it is subjected to freezing at $-20^{\circ} \mathrm{C}$ (Barbosa, 2009), emphasizing the importance of implementing good manufacturing practices and pasteurization as complements to the chain cold, in order to guarantee the food inocuity, in terms of the protozoan and other microorganisms.

In this case, the pasteurization heat treatment is an important practice used to obtain a high quality product with a longer and substantially free of microbiological contamination life inactivating heat sensitive microorganisms and enzymes such as polyphenol oxidases, which are responsible for deterioration of the product. Despite the efficiency, heat treatment can cause undesirable changes in the product, affecting nutritional and sensory attributes unattractive to consumers (Clement, 2002; Del Pozo Insfran et al., 2007).

Studies report that the sensory characteristics and consumer preferences are the main factors for choosing a product and their purchase intention (Roininen et al., 2001; Harker et al., 2003; Verbeke, 2006; Enneking et al., 2007). However, beyond the sensory characteristics, other aspects, such as information on labels, may interfere in the consumer's decision (Deliza et al., 2003; Deliza et al., 2005; Enneking et al., 2007).

This study aimed to evaluate, through affective sensory acceptance tests if the pasteurization information of açaí influences on product acceptance and purchase intention of consumers. The heat treatment is important to ensure a microbiologically safe food, since freezing as a preservation technique does not ensure the inactivation of any micro-organism, or the inactivation of the protozoan Trypanosomacruzi causes Chagas disease.

\section{MATERIAL AND METHODS}

This study was conducted at the Federal University of Rio de Janeiro (UFRJ) and included the implementation of an affective test to evaluate the acceptance and purchase intention of commercial samples of ready-to-eat pasteurized and unpasteurized açaí and the effect of information terms "pasteurized" and "unpasteurized".

Two brands commonly found in the markets were used, one for each product type since there is not a brand that produces both types ("pasteurized" and "unpasteurized"). To avoid differences from the processing of each brand, we selected the most consumed brands with a list of ingredients as similar as possible.

Participants were randomly selected in the university environment during two consecutive days. Bioprocess and food engineering students were excluded as volunteers since the probability of them knowing the definition of pasteurization is greater, not featuring the regular consumers.

The participants were divided into three groups of untrained assessors (consumers): the first group evaluated two samples without pasteurization information ( $P w$ and Uw, respectively, 
"pasteurized without information" and "unpasteurized without information"), the second group evaluated the pasteurized sample being aware of it ( $\mathrm{Pi}$, "pasteurized with information") and the third group evaluated the unpasteurized sample with this information (Ui, "unpasteurized with information").

\subsection{FREQUENCY OF CONSUMPTION}

Each participant received a consume frequency form in which they marked, on a 5 points scale, the consumption frequency for the studied product. Participants who do not consume açai at least once a month were excluded to avoid an unsatisfactory rating for not consuming the product often.

\subsection{ACCEPTANCE AND PURCHASE INTENTION}

Samples were coded with 3-digit numbers chosen randomly. Participants received these samples properly encoded in white plastic cups of $50 \mathrm{~mL}$, containing $20 \mathrm{~g}$ of sample.

To evaluate the acceptance and purchase intention of samples, different forms were distributed to groups. Participants in group 1 received two forms, one for each sample, which were presented, furthermore, following a balanced order of presentation. Participants in groups 2 and 3 received only one form as they evaluated one sample. In group 2 forms, the term "pasteurized" was highlighted in bold and underlined. In case of group 3, the form was highlighted with "not pasteurized açai".

In all the forms, a hedonic 9-point scale with endpoints "like extremely" and "dislike extremely" was used to assess acceptance and a structured 5-point scale ranging from "definitely would buy" to "definitely would not buy" was used to evaluate the purchase intention. The acceptance test results were evaluated by Student's t Test at 5\% significance using XLSTAT 2013.4.07 (Addinsoft).

\subsection{CONSUMER'S PASTEURIZATION CONCEPTS}

After acceptance testing, forms were distributed to ascertain if the assessors knew the definition of pasteurization. These forms were applied to analyze if there was influence of information, if that influence was generated only by the "pasteurized" and "unpasteurized" terms or the knowledge of the definition of pasteurization.

To set a standard criteria, answers with key terms such as "microorganisms elimination", "heating and cooling", "thermal treatment" were considered correct. Correct answers that did not present the main terms were considered incomplete and answers with inadequate terms were considered wrong.

The results were evaluated by tests of proportions with XLSTAT 2013.4.07 (Addinsoft).

\section{RESULTS AND DISCUSSION}

\subsection{PARTICIPANTS}

In total, 187 untrained assessors (consumers) completed the test, 64 in group 1, 57 in group 2 and 66 in group 3.In all groups there was a predominance of male participants, being $75.9 \%$ of the participants overall male and $24.1 \%$ female. The age range was between 18 and 23 years old, mean 21.7 years old.

Regarding the consumption frequency, $23.0 \%$ of the participants consumed once a month, $17.6 \%$ once every 15 days, $24.1 \%$ once a week, $20.3 \%$ twice a week and $15.0 \%$ more than twice a week.

\subsection{ACCEPTANCE AND PURCHASE INTENTION}

According to the results presented in Figure 1, for group 1, without information (samples Uw and Pw), the mean acceptance of unpasteurized açaí was statistically higher $(p<0.05)$ than the pasteurized açaí. Comparing the pasteurized samples, the sample of pasteurized açaí with 
information $(\mathrm{Pi})$ was more accepted $(\mathrm{p}<0.05)$ than the pasteurized sample without the information $(\mathrm{Pw})$. There was no statistical difference $(\mathrm{p}>0.05)$ between the sample of unpasteurized açaí with information (Ui) and the unpasteurized without information (Uw).

Therefore, the information increased $(p<0.05)$ the pasteurized açaí $(\mathrm{Pi})$ sample's acceptance which was not as well accepted by participants who have not received the information (Pw). However, the unpasteurized sample (Uw), which had a high acceptance without information, remained well accepted $(p>0.05)$, indicating that the "unpasteurized" information has not impaired the acceptance of the product. That is, the information had potentially positive influence (pasteurization) when the product did not have a very high acceptance potential and the negative information (not pasteurized) has not decreased the acceptance of the sample.

The pasteurized sample had a lower acceptance mean $(p<0.05)$ than the unpasteurized (both without information), but this claim increased $(p<0.05)$ the acceptance of the product that was not as well accepted. A similar result was found by Cox et al. (2012) that evaluated the effect of information on the acceptance of vegetables in the light of the claim about the presence of components that contribute to health. It was verified that the information contributed positively to increase acceptance only when the vegetable was initially not well accepted by consumers.

Analyzing the results, the information made the sample with the pasteurized information (Pi) not differ ( $p>0.05$ ), in terms of acceptance, from the unpasteurized sample without information (Uw). This demonstrates that providing the information to the participants generated an expectation or positive perception of the pasteurized sample, which caused an increase in its acceptance.

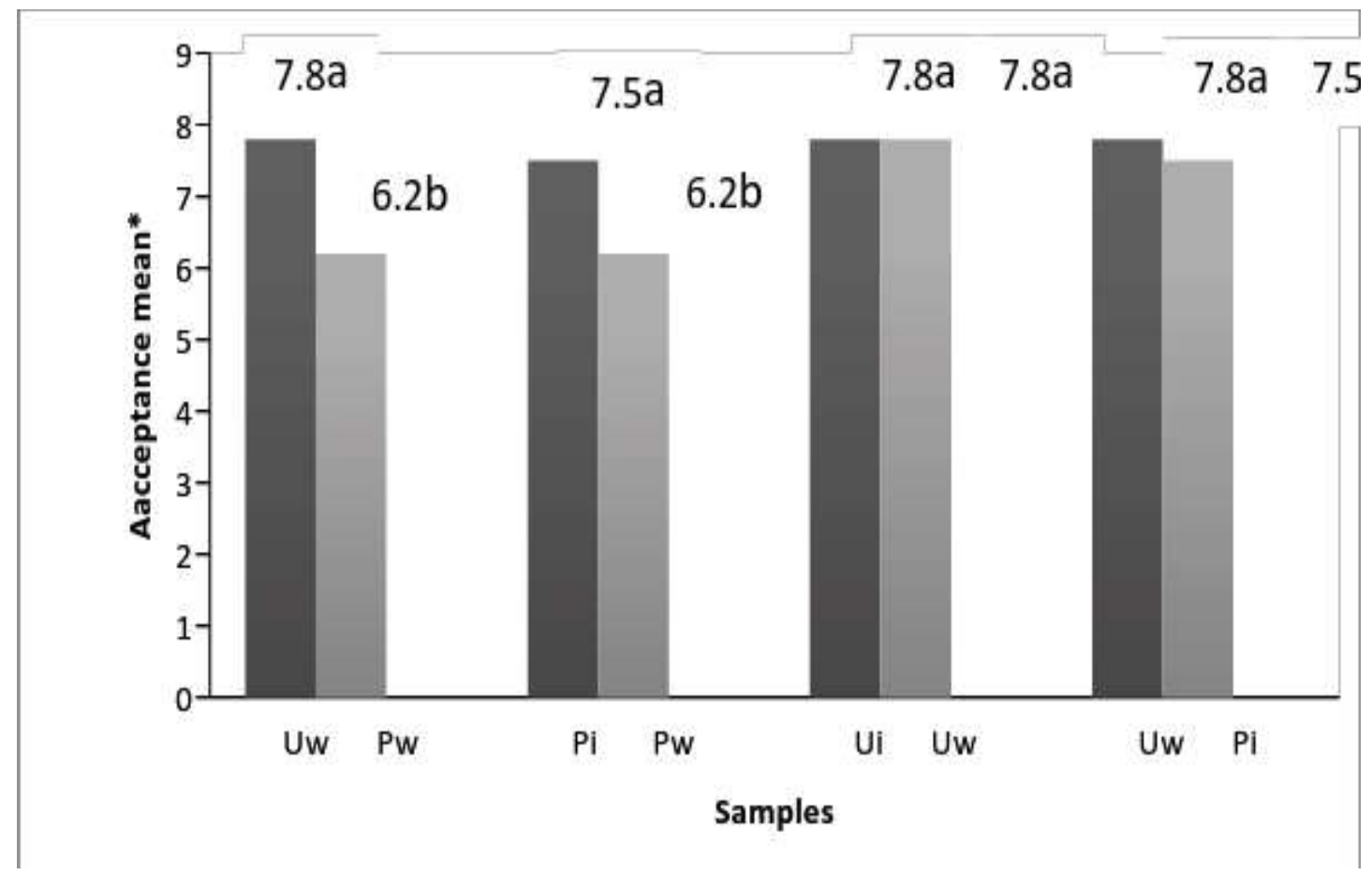

\section{FIGURE 1: STRUCTURED HEDONIC 9-PONT SCALE OF 9. SAME LETTERS IN PAIRS OF BARS INDICATE THAT SAMPLES WERE NOT DIFFERENT AT 5\% SIGNIFICANCE LEVEL ACCORDING TO STUDENT'S T TEST.}

Figure 2 presents the results related to purchase intention. Unpasteurized açaí samples presented better results regardless of the presence or absence of information. The unpasteurized sample without information obtained $54.7 \%$ notes "certainly would buy", followed by the unpasteurized sample with information which $53.0 \%$ of the assessors said they "certainly would buy". Pasteurized samples with or without information had, respectively, $33.3 \%$ and $25.0 \%$ of notes "certainly would buy". 
It was also observed that the notes "probably would buy" with information of the pasteurized samples (33.3\%) were higher compared to samples with no information $(25.0 \%)$, which was repeated in the notes "probably would buy", where percentages were respectively $52.6 \%$ and $35.9 \%$. Therefore, the use of the term "pasteurized" tends to positively influence purchase intention of participants, since the highest notes were given in the presence of the information.

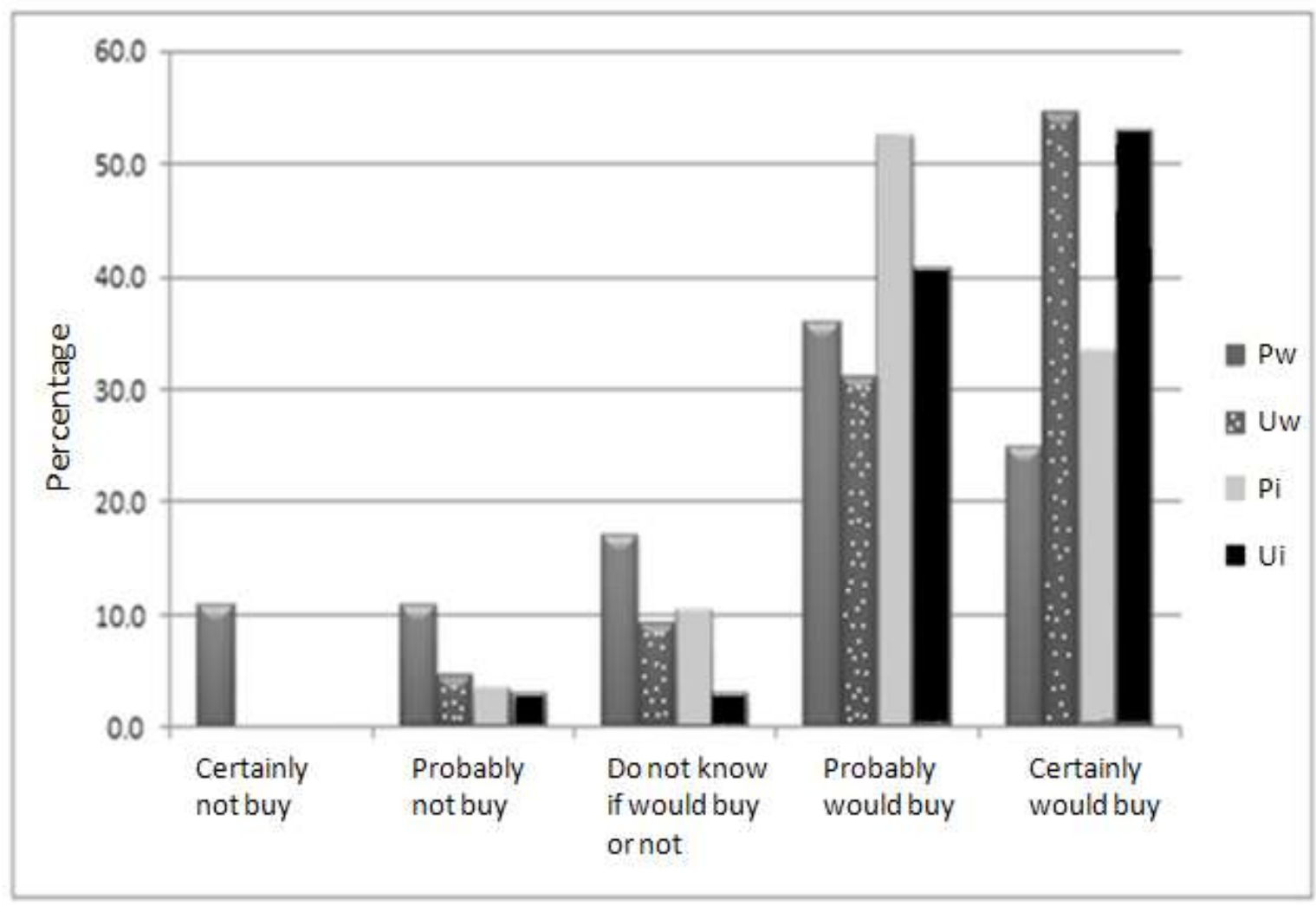

\subsection{CONSUMER' SPASTEURIZATION CONCEPTS}

In this study, a survey was conducted to assess the percentage of participants who reported knowing or not the concept of pasteurization, as seen in Table 1.The results demonstrated that pasteurization is an unknown process for the majority of the participants (57.8\%) since there was a significant difference $(p<0.05)$ between the proportion of yes / no answers for group 1.

\section{TABLE 1: EVALUATION OF SELF-REPORTED KNOWLEDGE ABOUT THE CONCEPT OF PASTEURIZATION AND CONSUMERS WHO CLAIMED TO KNOW THIS CONCEPT.}

\begin{tabular}{|c|c|c|c|c|c|c|c|c|c|c|c|}
\hline \multirow{2}{*}{ Group } & \multirow{2}{*}{ Members } & \multicolumn{4}{|c|}{ "Yes" / "No" answers } & \multicolumn{6}{|c|}{ Yes answers } \\
\hline & & Yes & $\begin{array}{c}\% \\
\text { Yes }\end{array}$ & No & $\begin{array}{c}\% \\
\text { No }\end{array}$ & Hits & $\begin{array}{c}\% \\
\text { Hits }\end{array}$ & Errors & $\begin{array}{c}\% \\
\text { Errors }\end{array}$ & Incomp. & $\begin{array}{c}\% \\
\text { Incomp. }\end{array}$ \\
\hline 1 & 64 & $25^{a}$ & 39.1 & $39^{b}$ & 60.9 & 12 & 12 & 7 & 28 & 15 & 60 \\
\hline 2 & 57 & $25^{a}$ & 43.9 & $32^{a}$ & 56.1 & 24 & 24 & 5 & 20 & 14 & 56 \\
\hline 3 & 66 & $29^{a}$ & 43.9 & $37^{a}$ & 56.1 & 13.6 & 13.6 & 4 & 24.2 & 16 & 62.2 \\
\hline Total & 187 & $79^{a}$ & 42.2 & $108^{b}$ & 57.8 & 22.8 & 22.8 & 16 & 20.2 & 45 & 57 \\
\hline
\end{tabular}

* Same letters in the same line indicate that the responses did not statistically differ at $5 \%$ significance level according to $z$ test for two proportions. 
Evaluating the yes / no responses (if the participant knows what pasteurization means) for the total group of participants $(n=187)$, there was a significant higher proportion $(p<0.05)$ of "no" answers. For groups 2 and 3, most participants claimednot knowing what pasteurization means, although there was no significant difference ( $p>0.05$ ). The generally higher number of "no" answers reinforces that it is reasonable to verify the effect of providing the information about the concept of pasteurization for consumers.

Considering participants who claimed to know what pasteurization means $(42.2 \%)$, only $22.8 \%$ actually had knowledge of the process, $57.0 \%$ had incomplete information (some understanding of the concept of pasteurization) and $20.2 \%$ did not know about the process. This result emphasizes the need of spreading the concept of pasteurization and its importance in the production of açaí, so that consumers become aware of the advantages of the pasteurized product. Once more, the effect of informing the concept of pasteurization and its effects on food could lead to greater acceptance of the product.

\section{CONCLUSIONS}

According to the results from the acceptance testing, unpasteurized açaí is more accepted than pasteurized, in the absence of information. The information only influenced the sample that did not present high acceptance in acceptance testing, ie, the pasteurized sample. This influence was potentially positive, as it significantly increased acceptance in the presence of information, reaching no difference from unpasteurized sample.

Regarding the purchase intention, unpasteurized sample also showed best results. However, the information positively influenced the pasteurized samples, increasing purchase intention.

The consumer awareness of pasteurization is limited, given that less than half of the participants declared to know the concept of pasteurization and, amongst those, most missed or answered incompletely, showing the potential of verifying the effect of providing pasteurization concept and benefits on consumers' acceptance in a future study.

\section{RESUMO}

\section{VERIFICAÇÃO DO EFEITO DA INFORMAÇÃO DE PASTEURIZAÇÃO NA ACEITAÇÃO E INTENÇÃO DE COMPRA DE AÇAÍ PRONTO PARA CONSUMO}

O Brasil é o maior produtor de açaí do mundo, com destaque para o Estado do Pará. Além do mercado local na Região Amazônica do país, o produto também conquistou outras regiões do mercado nacional e internacional, devido às suas propriedades nutricionais e funcionais. Entretanto, o açaí é muito perecível, graças à sua natureza susceptível a ação microbiana e as suas características químicas e enzimáticas. Adicionalmente, evidências vêm apontando o açaí como veículo de transmissão oral da Doença de Chagas Aguda (DCA) na região Norte do País. A pasteurização é um processamento térmico importante na indústria de alimentos, pois contribui para um alimento seguro, do ponto de vista microbiológico. Entretanto, o calor pode afetar características sensoriais importantes como a cor e o sabor e diminuir a aceitação do açaí. Por outro lado, informações sobre o produto podem interferir na escolha dos consumidores e na sua intenção de compra. Assim, o objetivo deste trabalho foi analisar se a informação de pasteurização do açaí pronto para consumo modifica a aceitação e a intenção de compra dos consumidores. $O$ estudo foi realizado a partir da análise sensorial de duas marcas comerciais de açaí pronto para consumo, uma pasteurizada e outra não pasteurizada. Foram realizados testes afetivos de aceitação com as amostras, utilizando-se a escala hedônica estruturada de nove pontos ( 1 = desgostei muitíssimo a 9 = gostei muitíssimo). Além disso, foram avaliadas a frequência de consumo, e a intenção de compra 
dos consumidores através da escala estruturada de cinco pontos $(1=$ certamente não compraria a $5=$ certamente compraria). Para verificar se os avaliadores tinham a correta interpretação do conceito de pasteurização, fichas fazendo este questionamento foram entregues e respondidas. Foi possível comprovar que a informação de pasteurização, dada aos avaliadores, aumentou $(p<0,05)$ a aceitação da amostra pasteurizada $(7,5 a)$, que inicialmente sem a informação não foi tão bem aceita $(6,2 b)$ quanto à amostra não pasteurizada $(7,8 a)(p<0,05)$. Apesar disso a informação de não pasteurização não influenciou na aceitação da amostra não pasteurizada $(7,8 a)$, que continuou sendo bem aceita $(p>0,05)$ pelos avaliadores $(7,8 a)$. Estes resultados reforçam a importância do efeito da informação sobre a aceitação do açaí e intenção de compra dos consumidores.

PALAVRAS-CHAVE: PASTEURIZAÇÃO, AÇAÍ, EFEITO DA INFORMAÇÃO, TESTE DE ACEITAÇÃO, INTENÇÃO DE COMPRA.

\section{REFERENCES}

1 Barbosa RL (2009) Oral transmission of Trypanosoma cruzi by açai pulp in mice. Master dissertation in Animal Biologoy. Universidade Estadual de Campinas, Instituto de Biologia, Campinas.

2 Brazil (2012) Ministry of Health Surveillance Secretary of Health Epidemiology and Health Services / Office of Surveillance in Health Volume 21 - Issue 2.

3 Clement E (2002) Peroxidase from oranges (Citrus sinenses (L.) Obsbeck). European Food Research Technology, 215:164-168.

4 Cox DN, Melo L, Zabaras D \& Delahunty CM (2012) Acceptance of health-promoting Brassica vegetables: the influence of taste perception, information and attitudes. Public Health Nutrition, 15:1474-1482.

5 Deliza R,, Rosenthal A \& Silva ALS (2003) Consumer attitude towards information on non conventional technology. Trends in Food Science and Technology, 14:43-49.

6 Deliza, R., Rosenthal, A., Abadio, FBD, Silva, $\mathrm{CHO}$ \& Castillo, C. (2005). Application of high pressure technology in the fruit juice processing: Perceived benefits by consumers. Journal of Food Engineering, 67, 241-246.

7 Del Pozo Insfran D et al. (2007) Copigmented Anthocyanins and Stability of Ascorbic Acid in Muscadine Grape Juice Processed by High Hydrostatic Pressure. Journal of Food Science, 72:247-253.

8 Enneking U, Neumann C \& Henneberg S (2007). How important intrinsic and extrinsic product attributes Affect purchase decision. Food Quality and Preference, 18:133-138.

9 Harker SF, Gunson FA \& Jaeger SR (2003) The case for fruit quality: an interpretive review of consumer attitudes, and preferences for apples. Postharvest Biology and Technology, 28:333-347.

10 Menezes EMS (2005) Effects of high hydrostatic pressure in açaí pulp pre-frozen (Euterpe oleracea Mart.). Master dissertation in Food Science and Technology, Federal Rural University of Rio de Janeiro, Seropédica, RJ. 83pp.

11 Menezes EMS, Torres AT, Saba AU (2008) Nutritional value of acai pulp (Euterpe oleracea Mart.) lyophilized. Acta Amaz, 38, n.2, Available at: <http://www.scielo.br/scielo.php?script=sci_arttext\&pid=\$004459672008000200014\&lang $=p t>$. Acessed: 05.13.2014.

12 Queiroz M, Cunha, SC \& Rogez H (1998) Impact of pasteurization in acai juice (Euterpe oleracea Mart.) on peroxidase activity. In: Congress Of Brazilian Association Of Chemistry, 1998 São Luís - MA. Summary QA 99, p.171-172.

13 Rogez H (2000) Acai: preparation composition and improvement of conservation. 1st ed. Bethlehem, PA: Ed Federal University of Pará - EDUFA, 313 p.

14 Roininen K, Tuorila H \& Zandstra EH et al. (2001) Differences in health and taste attitudes and behavior among Reported Finnish, Dutch and British consumers: a cross-national validation of the Health and Taste Attitude Scale (HTAs). Appetite, $37: 33-45$.

15 Sousa CL, Melo GMC \& ALMEIDA SCS (1999) Quality assessment of the acai sold in the city of Macapa - AP. Bulletin CEPPA, 17:127-136.

16 Steps LAC, Guaraldo AMA, Barbosa RL, Dias VL, Pereira KS, Schmidt FL, Franco RMB \& Alves SD (2012) Infectibilidade and survival of Trypanosomacruzi in açaí pulp: a study in vitro and in vivo. Epidemiol. Serv. Health, 21:223-232.

17 Verbeke W (2006) Functional foods: consumer willingness to compromise on taste for health? Food Quality and Preference, 17:126-131. 